\title{
HOW DOES NUTRIENT AVAILABILITY AFFECT THE POPULATION DYNAMICS OF THE INVASIVE NEW ZEALAND MUD SNAIL (POTAMOPYRGUS ANTIPODARUM)?
}

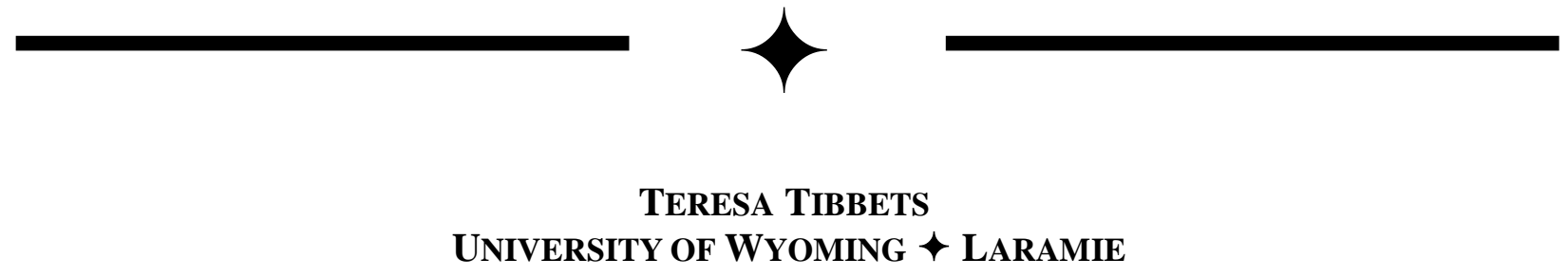

\section{$\downarrow \quad$ INTRODUCTION}

A primary goal of invasion biology is to predict which introduced species become invasive and which systems are susceptible to invasion. Therefore it is vital to understand how invasive species sustain positive population growth rates in their introduced range and what environmental factors control population growth. The New Zealand mud snail (Potamopyrgus antipodarum) (Figure 1.) has spread throughout Europe, Australia, and North America, and has reached pest densities in many streams in the Greater Yellowstone Area (GYA) since their introduction in the 1980's. High rates of growth and secondary production have been documented for mud snails in its introduced range in the GYA, as have evidence of negative interactions between mud snails and native macroinvertebrates and higher trophic levels. However, little is known about how the availability of nutrients affects the invasion success of mud snails.

Laboratory experiments have shown that the growth and fecundity of mud snails is negatively affected when fed algae with a low phosphorus content. These experiments provided evidence that phosphorus availability, and potentially other nutrients such as nitrogen, could limit the population growth and spread of mud snails and help to explain their distribution with the GYA.

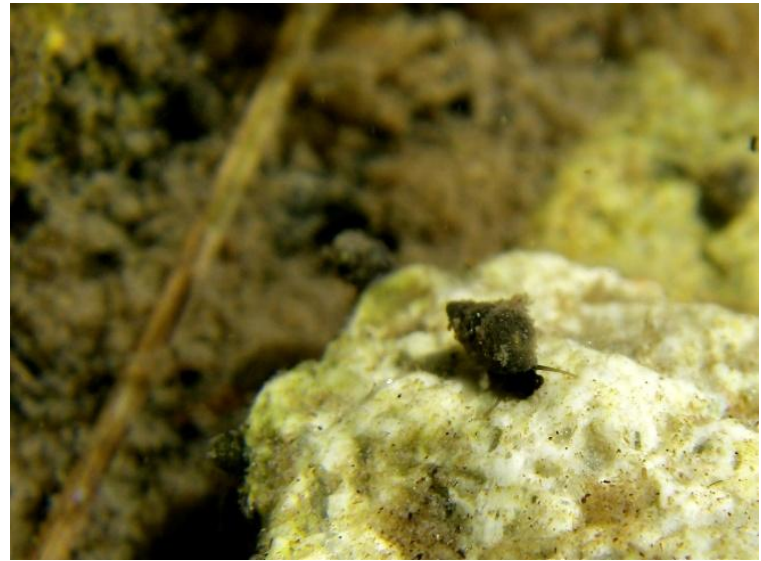

Figure 1. Potamopyrgus antipodarum feeding on rock biofilm in Polecat Creek. Photo by Madeleine Mineau.

\section{$\uparrow \quad$ MeTHODS}

In order to study how algal food quality affects mud snails in streams in the GYA, I first set out to study the $\mathrm{P}$ content of the rock biofilm that mud snails consume. In June of 2009, I conducted a field study to measure the carbon, nitrogen, and phosphorus content of the rock biofilm resources available to mud snails at Polecat Creek. I "spiked" the algal biofilm to increase its $\mathrm{P}$ content by placing tea balls filled with stream gravel into a bucket full of stream water and varying levels of Potassium phosphate that mimicked high and low levels of phosphorus availability. I sampled the biofilm growing on the gravel at time 0 (initial), and again after 48 hours in the low and high $\mathrm{P}$ treatments. 


\section{$\uparrow \quad$ RESUlTS}

The initial samples had a mean $\% \mathrm{P}$ of $0.31 \%$, which is typical for rock biofilm in Polecat Creek. After 48 hours in the $\mathrm{P}$ addition treatments, the low $\mathrm{P}$ treatment mean value was $0.15 \% \mathrm{P}$, whereas the high $\mathrm{P}$ treatment was $0.33 \% \mathrm{P}$ (Figure 2).

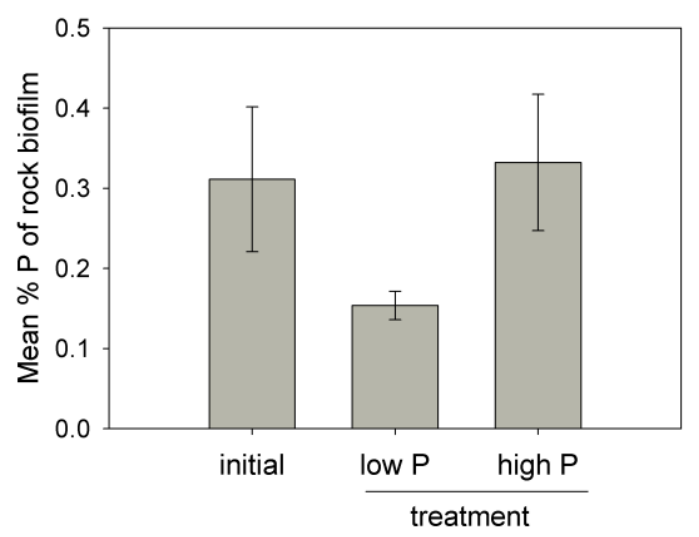

Figure 2. The rock biofilm in the low $\mathrm{P}$ treatment had a reduce $\mathrm{P}$ content compared to the initial and high $\mathrm{P}$ treatment after 48 hours.

\section{$\uparrow$ DISCUSSION}

These results were slightly surprising, since I had assumed both $\mathrm{P}$ treatments would increase the overall $\mathrm{P}$ content of the biofilm growing on the gravel. Instead, it appears that rapid biological uptake decreases the amount of $\mathrm{P}$ available over time to the biofilm in the buckets. Therefore, I can actually create a larger range of algal $\mathrm{P}$ content treatments since I can manipulate the mean $\mathrm{P}$ content of the biofilm to be lower than what is typical in the stream. These results will be very useful when I set up future growth and fecundity experiments at Polecat Creek to determine how nutrient availability affects mud snail success. 